\title{
Preparing Independent Golden Millennial Generation Through Character Education
}

\author{
L Listyaningsih* \\ Civic Education \\ Universitas Negeri Surabaya \\ Surabaya, Indonesia \\ listyaningsih@unesa.ac.id
}

\author{
Septina Alrianingrum \\ History \\ Universitas Negeri Surabaya \\ Surabaya, Indonesia \\ septi@unesa.ac.id
}

\author{
S Sumarno \\ History \\ Universitas Negeri Surabaya \\ Surabaya, Indonesia \\ sumarno@unesa.ac.id
}

\begin{abstract}
The superior generation is the millennial generation who has the responsibility of welcoming the golden generation in 2045. The development of science and technology in the era of the industrial revolution 4.0 has changed various aspects of life towards 5.0 society. To prepare the superior generation of the Indonesian millennial generation to realize the golden generation of Indonesia in 2045, students as the superior and millennial generation need to be prepared in facing social, cultural, work world changes and advances in science and technology and big data digitization. Therefore, we need an educational process that links and matches the industrial world and global changes in the future without leaving a noble character. Education is a form of characterbuilding process for the millennial generation. as the nation's next generation. Character education is important as a vehicle for the process of forming a good personality as social capital, namely a moral force that is intelligent, optimistic, tough, trusting, and patriotic. Efforts to improve the quality of character education in the era of the industrial revolution 4.0 and society 5.0 require a change in mindset, being smart, responsible, and competitive. The independent campus learning curriculum policy launched by the Ministry of Education and Culture through the Regulation of the Minister of Education and Culture No. 3 of 2020 is one of the golden bridges in welcoming the preparation of the millennial generation to the golden generation. Based on the results of the research questionnaire conducted, data were obtained about the importance of character education textbooks for the millennial generation. This book is presented in an attractive, pictorial form.
\end{abstract}

\section{Keywords--character education, the millennial generation}

\section{INTRODUCTION}

The development of science and technology in the era of the industrial revolution 4.0 has changed various aspects of life, especially the pattern of education, social interaction, and culture to pick up the society 5.0 society. This situation encourages tertiary institutions as one of the elements of education to respond through the transformation of education to a superior generation with global competitiveness but character without having to leave the noble cultural roots of the nation.

To prepare a superior generation of Indonesia's millennial generation, students as part of realizing Indonesia's golden generation in 2045 must be ready to face changes in society. As a result of advances in science and technology, there have been changes in various fields of life such as social, cultural, the world of work, and so on. This global change must maintain the noble character of the Indonesian people.

Education is one form of the process of building the character of the nation's next generation. Education is one of the processes of forming human beingsintelligent, intellectual, critical thinking, creative and innovative and able to develop noble values as a foundation in life. Education without a teacher is like a room without light. This strategic role in the historical education environment of the Faculty of Social Sciences and Law, State University of Surabaya is one of the references to develop a character based on the noble values of the nation's culture and awareness of the nation's history. Through curriculum and infrastructure and appropriate learning methods, the character is expect to be realized as the goal of national character development and education for the millennial generation towards Indonesia's golden generation in 2045.

Efforts to improve the quality of character education in the era of industrial revolution 4.0 and society 5.0 require a change in mindset, being smart, responsible, and competitive. This balance of academic intelligence, character, spiritual and social awareness needs to be prepared from now on. The independent campus learning curriculum policy announced by the Ministry of Education and Culture through Permendikbud No. 3 of 2020 is one of the golden bridges in welcoming the preparation of the millennial generation towards the golden generation. Students as agents of change who are skilled, creative, innovative, flexible, resilient (agile learner), and as a moral force need a study guide in the form of textbooks that are in line with the mental development of the millennial generation.

Textbooks on Character Education are an important part of building the basic character of national social attitudes to become community figures who humanize humans. The value and character education course at UNESA is one of the media to create ideal character education for the millennial generation. Based on UNESA'S academic manuscript in Parwa 3 regarding curriculum implementation, it has paid attention to efforts to develop student character as millennial generation according to UNESA'S motto "Growing with Character" through the Jelita Idaman pattern (faith, smart, independent, honest, caring and tough) [1].

Character education is important as a container for the process of forming a good personality in social capital, namely a moral force that is smart, optimistic, tough, trusting, and patriotic (The Importance of Character Education in the World of Education, 2019). Licona 
explained that character education is a deliberate effort to help humans understand, pay attention to and apply the values that are obtained as core ethics [2]. Character as a unique value - good and real in life is inscribed in every individual, manifested in behavior and attitudes into a result of thought, heart, feeling, and initiative from a group of people or individuals to be strong/tough in facing difficulties and challenges of the millennial future.

The independent campus as a forum for contextual learning that is centered on students (student-centered learning) provides challenges and opportunities to develop creativity, personality, independence, inquiry, collaboration, and dynamically hard and soft skills according to their talents and interests. Through the concept of independent learning for the millennial generation, according to Licona emphasized that free learning to look for noble characters must pay attention to moral concepts (moral knowing), moral attitude (moral felling), and moral behavior (moral behavior) to always want to do good and do good deeds.

The preparation of character education textbooks in the history education study program aims to (1) foster systemic collective behavior in realizing national life that is following the basis and ideology and collective civilized potential, (2) forming a competitive, noble, moral, patriotic, strong generation, contemporary dynamics imbued with a devout faith in God based on Pancasila, (3) developing the spirit of civilized nationalism as human beings who humanize humans according to the noble values of the socio-cultural character of society, and (4) forming attitudes and personalities that are globally competitive without having to conflict with prevailing norms so that they are widely beneficial to the surrounding environment as an agent of change, social capital, and moral force

\section{METHODS}

This research is development research with a procedural model using the ADDIE. This model is conceptual analytic by applying steps to prepare the concepts and product components created and analyzing them in detail and showing the relationships between the components developed according to learning outcomes.

The research procedure is carried out according to the ADDIE Model stages, namely (1) analyzing the need for the importance of character education textbooks in the concept of an independent learning curriculum and designing textbook forms that are under the learning styles of the millennial generation who are free-spirited, (2) compiling concept designs and systematic book chapters character education and validated by material experts, (3) limited trial of textbook drafts on a sampling of class B class 2017 students who have taken value and character education courses in the previous semester to fill out a questionnaire about evaluating the feasibility of textbooks, and (4) dissemination of textbooks to students of class 2019 who are taking values and character education courses in the even semester of the 2019/2020 academic year at the FISH Unesa history education study program.

The type of data for analysis was obtained from the results of questionnaire data filled out by students of class 2019 with a Likert scale evaluation form. Meanwhile, the data collection instruments apart from the questionnaire filling data also came from the validation results of the material experts. The feasibility aspect of this textbook is seen from the items of suitability, accuracy, updating, and effectiveness of the learning process.

Data analysis was carried out through a descriptive analysis process from the results of the questionnaire which consisted of 3 sub-aspects of feasibility, namely (1) the usefulness and effectiveness of textbooks, there were 5 questions, (2) the physical convenience of textbooks, there were 4 points, and (3) contents and the completeness of textbook content, there are 11 questions. The data analysis is described in a descriptive-analytical manner equipped with a percentage graph.

\section{RESULTS AND DISCUSSION}

This research produces textbooks as product output and research reports to analyze the results of the feasibility of textbooks for millennial generations who are free to seek independent learning resources. The Character Education textbook product contains 6 main chapters of discussion, namely (1) an introduction that discusses the importance of value and character education in the global era based on big data and metadata as skills to understand digital literacy as an independent learning process, (2) value education in a global manner. detailed under the characteristics, classification, and philosophy, (3) education of values and attitudes to understand the nature of norms and morals whose functions affect the character being studied,

The teaching material is then validated by material experts. The validation of the content expert is intended to analyze the appropriateness of the content in the textbook, its effectiveness, and to study historical sources under their respective competencies. After this stage, a limited trial was carried out to observe social activities.

Based on the results of the analysis of the instrument items, the indicator of the suitability of the material with the competence is a supporting indicator of learning material. Meanwhile, material experts analyze the accuracy of the material. From the questionnaire aspect to measure the usefulness of character education textbooks for the millennial generation, there are 12 questions obtained by 20 students who agree that the textbook can be seen below, the results of the pooling appear in some of the pie charts below.

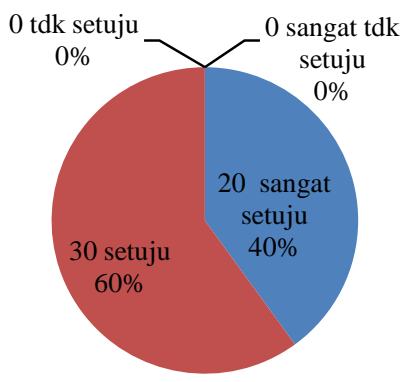

Fig. 1. Textbook percentage increases Comprehension 
Based on the results of the analysis of the ease of use of character education textbooks, it is found that there is an instrument item that indicates the suitability of the material with competence as a supporting indicator of learning material. Meanwhile, 33 students agreed because it facilitates the independent learning process as a part of independent learning on this independent campus.

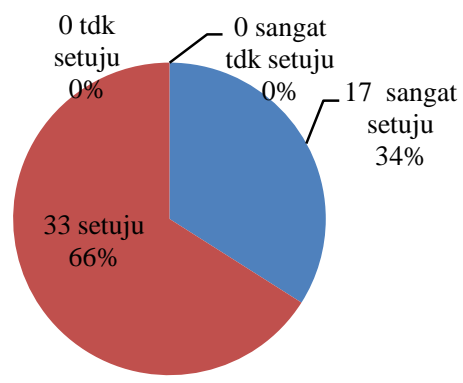

Fig. 2. Percentage of Textbooks Makes Easy Learning

Based on the results of the pie chart analysis, it was found that the instrument items were the indicators of the suitability of the material and the competence as a supporting indicator of learning material. Meanwhile, material experts analyze the accuracy of the material. From the questionnaire aspect to measure the usefulness of character education textbooks for the millennial generation, there were 12 questions obtained by 20 students who agreed that the textbook was very helpful and made it easier to understand the material presented.

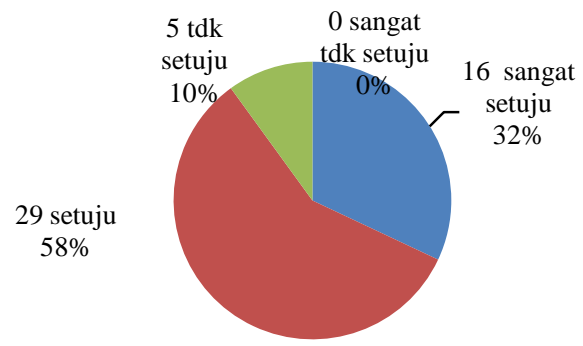

Fig. 3. Percentage of Textbooks Encouraging Independent Learning

In addition to student questionnaires with a Likert scale, in this instrument, there is an open question field that measures the appropriateness of character education textbooks for the independent millennial generation. As for suggestions and criticisms from the results of limited dissemination, there are several inputs, namely: (1) this textbook can be a source of learning and can understand the contents and messages of the character of the book so that the motivation of students as millennials to be free to think critically but responsibly grows; (2) The selected items with 5 rating scales strongly agree to strongly disagree. This is an indicator of measuring attitudes and behavior of the millennial generation that can independently adapt to the surrounding environment while clearly understanding the nature of learning character education; (3) Textbooks help millennial generations learn to understand what is happening around their environment so that they can respectfully respect the socio-cultural and economic environment; (4) Textbooks are very helpful cognitive and direct the concept of attitudes, values and ideal behavior with character

While some of the criticisms and suggestions for improving this textbook are (1) the summary of the material at the end of the chapter is not equipped with pictures as a learning medium; (2) Textbooks that are made sufficiently complete in fulfilling the attainment of applicable norms for the continuation of community rules towards a future morality society; (3) Providing information about quotations as part of a reference to facilitate independent learning on a timely basis because it is open and free of responsibility; (4) The existence of educational textbooks makes it easy to learn the material and theoretical concepts that are easy to implement in the environment of each millennial generation; (5) It needs to be developed and perfected so that the textbook needs to be given footnotes as reference material for the book to be compiled.

Based on the results of the material expert validation assessment, it was obtained data that this character education textbook was feasible and good $(94.4 \%)$ to be used as teaching material in history education study programs in the independent campus learning curriculum. From the aspect of total textbook effectiveness, it is argued that $100 \%$ is deemed necessary and a competent book is needed.

The results of the distributed questionnaire showed that the aspects of the usefulness of the textbook according to the millennial generation $30 \%$ strongly agree and $65 \%$ agree. This shows that the millennial generation with an independent spirit needs a book guide on character education in the global era and in the context of a civilized society 5.0. While the overall average questionnaire results show the importance of this character education textbook for the millennial generation, namely $22 \%$ strongly agree, $70 \%$ agree and $7 \%$ disagree.

\section{Discussion}

\section{The Importance of Character Education}

Textbooks become handbooks compiled by experts in related fields according to textbook rules and for distribution [2]. Based on the Guidelines for Curriculum Development in the UNESA Parwa 3 academic text on curriculum implementation, an important aspect that needs to be considered in each study program is the obligation to develop the character of UNESA students. The character of UNESA students is directed under the motto of UNESA growing with character, which includes Faith, Intelligence, Independent, Honest, Caring, and Resilient (Idaman Jelita) [1]. The importance of this character education textbook for the millennial generation is $22 \%$ strongly agree, $70 \%$ agree and $7 \%$ disagree. This character education textbook is feasible and good $(94.4 \%$. total textbook effectiveness believes that $100 \%$ is deemed necessary and needed a competent book.

The importance of character education especially for students in the world of education, because character education is used as a forum or process to shape students' personalities to become good personalities. Character education aims to shape Indonesian people who are moral, 
Indonesian people who are intelligent and rational, form people who are innovative and like to work hard, are optimistic and believe, and have a patriot spirit [3]. Lickona stated that the notion of character education is a deliberate attempt to help someone so that he or she can understand, pay attention to, and practice core ethical values. [4].

National Character Development is a collective-systemic effort of a nation-state to realize the life of a nation whose state and basis are under the basis and ideology, constitution, state direction, and collective potential in the context of civilized national, regional and global life. All of that to form a nation that that is strong, competitive, noble, moral, virtuous, tolerant, cooperative, patriotic, dynamic development, science-oriented, all of which are imbued with faith and piety to God Almighty based on Pancasila. The development of the nation's character is carried out coherently through the process of socialization, education and learning, empowerment, civilization, and cooperation of all components of the nation and state.[3].

Character education can be used as a strategy for overcoming ever-changing experiences to form a solid identity for each individual. This Textbook gives value to the importance of character education to form a collaborative attitude with the progress of the times without having to conflict withthenormapplicable. This Textbook is used as a vehicle for socializationcharacter which should be owned by each individual to make them as individuals who are of greatest benefit to the environment around. [5].

The scope of the content of the Value and Character Education textbook is (1) Chapter I Introduction, discusses the importance of value and character education, as well as the scope of the Character Value education material; (2) Chapter II, discusses the education of values and attitudes, (3) Chapter III, discusses norms and morals for human life, sources of moral values in life, the relationship between norms and morals, the implementation of value education, norms and morals in Indonesia, (4)Chapter IV, discusses ethics and manners in everyday life, (5) Chapter V, discusses the education of character and noble character in schools, the community environment; having a state and religion, (6) Chapter VI, discusses character education in various nations, in Indonesia, in schools, in society and independently chooses and chooses the appropriate character behavior and responsibilities in life.

The role of this value and character education textbook has a very important meaning for the millennial generation towards the ideals of the golden generation in 2045. This textbook supports the mastery and assignment of courses by students. Besides that, it needs to be further developed so that it can become a reference book whose format and quality are under reference standards. This book aims to prepare the golden generation in 2045 to support the development of moral force and agents of change in society based on the noble values of Pancasila. [6] The single meaning of the various noble values of Pancasila needs to be united in one perspective and one paradigm. Pancasila has become a reference, benchmark, paradigm for the development of the nation's character within the Indonesian nation's diversity habitus. The value of togetherness becomes the foundation for habituation the values of kinship and kinship. The value of cooperation as the essence of the nation's cultural character in every ethnicity can be a social capital and a national cultural capital [6]

Realizing ideal textbooks is not easy, because compiling textbooks requires time and money. If the lecturer succeeds in compiling textbooks, publishing, and selling at their own expense also feels heavy. Especially if the number of students is only limited in the classic would be difficult for the amount that the students could afford. Likewise, marketing itself for lecturers is certainly very difficult.

This policy fund research at least can provide opportunities for lecturers to compile and produce textbooks. Because by compiling textbooks, lecturers will get several benefits at once, namely: fulfilling credit points for research credit figures, the results are in the form of books that can meet teaching credit numbers, and if produced scientific journals can also meet scientific paper credit numbers.

In addition to fulfilling credit numbers through textbook development research, textbooks are also fulfilled that can be used as a reference for the courses they are taking, as well as for students who also have references that can be used as a reference for the courses they are taking.

\section{Preparation of Millennial Generation Character}

Character education is the most important context in the 21 st century learning to overcome moral crises. The millennial generation with independent spirits needs a book guide on character education in the global era and the context of a civilized 5.0 society. An independent campus as a forum for contextual learning that is centered on students. free learning to look for noble characters must pay attention to moral concepts (moral knowing), moral attitude (moral feeling), and moral behavior (moral behavior) to always desire to do good and do good deeds [7].

Character education is closely related to moral education. Good character is supported by knowledge of kindness, the desire to do good deeds [4]. Character is unique values good (knowing the value of goodness, willing to do good, and have a good life) are embedded in oneself and embodied in attitude Character coherently emanates from the results of thought, heart cultivation, feeling, and intention, as well as sports of a person or group of people [8]. Character is a characteristic of a person or group of people who contain values, abilities, moral capacities, and toughness in facing difficulties and challenges. [4].

Character education that is applied systematically and continuously will make someone emotionally intelligent. This social intelligence is an important provision for the future to face all kinds of life and academic challenges. Character education is the key to individual success [7]. Independent character, academically intelligent, independent, and responsible are expected to become a complete personality that reflects the harmony and harmony of the heart (honesty and sense of responsibility), thought (intelligence), body (health and cleanliness), as well as feeling (care) and intention ( skill and creativity) [8].

Character education aims to form a nation that is tough, competitive, hasa noble character, moral, high tolerance, cooperation, patriotic spirit, dynamic development, science 
and technology-oriented, all of which are imbued with faith and piety to God Almighty based on Pancasila [5]. The Free Learning Curriculum in UNESA's Campus is important to make this happen. Millennial generation free spirits who have high digital literacy skills need to be accompanied.

The process of globalization has an impact on changing the character of society, including in Indonesia. Lack of character education will lead to a moral crisis which results in negative behavior. The process of character development is influenced by many factors characteristic of oneself (nature) and the environment (nurture) when this generation grows and develops. Environmental factors are within the reach of society and individuals. Environmental engineering and establishment require appropriate strategies in school culture, school management, curriculum, educators, and teaching methods [7].

The results of social awareness in value and character education for the independent millennial generation are good manners and morals. Social manners as a rule of life flow naturally in human relationships. Manners are closely related to ethics and norms that give birth to morals. Guidelines for the right way of life in this global millennial era need to be seen from the point of view of culture, morals, religion, and global communication [7]. This social awareness can be realized when etiquette animates the behavior and attitudes of each individual in living together. Conceptually, this activity includes guidance, habituation, teaching, and training, as well as exemplary to prepare the millennial generation to become whole human beings with noble character in all their roles in the future. [8]. This effort to form a whole person produces a reflection in words, actions, attitudes, thoughts, feelings, and works based on religious values as well as norms and noble morals of the Indonesian nation for each millennial generation.

The 21st-century education model which has important things to think critically in sorting out and selecting creative, innovative, communicative, collaborative, and solution problem-solving processes needs a form of high and global social awareness. The ability of digital literacy encourages the millennial generation to become independent in displaying their attitudes and behaviors in a smart, positive, and solution way to answer the challenges of global life. The quality of 21 st-century education is an indicator of the success of character education for the millennial generation. The ability of IESQ (intelligence, emotional, spiritual Quation) is a barometer of realizing the great character of the 2045 millennial golden generation. The MBKM curriculum and complex digital literacy skills are a reference for this golden generation to pick up its future with character and dignity.

Pancasila is a platform for identity building as well as a paradigm for the character of the millennial Indonesian nation. It is hoped that Imagined Communities with Pancasila can make the noble socio-cultural values of the nation as a guide for the nation's basic character education. The basic value that the community maintains as the sociocultural capital of the nation is the continuity of the imagined communities. The interpretation of Pancasila as the capital of ethnic-habitus becomes the basis for mapping the internalization of national character education in the millennial era. Freedom of interpretation of values in attitudes and community perceptions needs to be made a real platform along with the mental development of the nation.[6]

Characterized social awareness is the speed of personal abilities in self-understanding, emotions, mood management, active interpersonal awareness, empathy, environmental needs, ability to adapt, friendly, loyal friends, and able to solve personal problems in a solution. This will manifest a positive attitude, essential mindset, normative commitment, and ability competence in preparing a millennial golden generation who is independent with responsibility and character. Understanding, actions, attitudes, and good behavior as manners in character education can become a habit in building a life together as a community, nation, and citizen.

The current globalization and modernization of life have made the personal abilities of every individual Indonesian nation need a real platform in the process of character building. The original cultural elements as the basic norms of the noble values of the nation which are formulated in the Pancasila philosophy encourage the need to organize a character mapping that is by following per under the sociocultural values of the national community itself. [9]. From the cultural attitude of the Indonesian nation so far, it appears that most Indonesians want and continue to try to make the noble values of their nation's traditions still underlie the character and personality of the millennial generation. This effort can be seen in the context of family and environmental education which still makes up a lot of defensible community habits. Understanding cultural milestones is the basic essence of national character through new freely interpreted symbols under experience, education, and cultural values itself (Hoed, 2016).

The concept of cultural nationalization for the development of national character ala Ki Hajar Dewantara as an informal platform was formulated by SartonoKartodirdjo in five principles, namely (1) unity, unity, (2) equality, (3) personality, (4) freedom ( liberty), and (5) performance (achievement). This essence is also seen in the value of the Pancasila principle of the basic principles of national character building for $\mathrm{Ki}$ Hajar Dewantara who adopted Montessori thinking which optimizes free but responsible personality intelligence combined with Rabindranath Tagore's thoughts as a process of modification and transformation of the concept of character education in Indonesia [9]. This encourages the implementation and internalization of the noble values of Pancasila in everyday life as the moral force of society towards millennial dynamics. Pancasila as the motor of the dynamics of national life and socio-cultural attitude can be an embryo of a modern character that can be adapted to the concept of western democracy, Islamic modernization, and the local traditions of the nation [10].

\section{IV.CONCLUSION}

The character education textbook contains 6 main chapters of discussion, namely about the scope and importance of character education, understanding value education, character, values, and norms in the life of the 
surrounding environment. Meanwhile, the last chapter discusses the patterns of character education and noble morals from various nations that can be filtered and the pattern of character education in Indonesia. The results of the notes on the questionnaire sheet obtained data that the preparation of character education textbooks could be equipped with illustrated images, concept mapping, and summaries. While the suggestions from the results of the discussion above can develop all educators to provide the foundation and importance of character education and how it is implemented in everyday life.

\section{ACKNOWLEDGMENT}

This textbook is the result of the work of the policy research of the faculty of social science and law which provides opportunities for researchers to develop their tridharma.With research, this policy fund can at least provide opportunities for lecturers to compile and produce textbooks. The benefits of preparing this textbook are to fulfill research credit points as well as teaching competencies. Policy research funds are very beneficial for lecturers to produce work and develop further textbooks.

\section{REFERENCES}

[1] M. Ibrahim, "Unesa Academic Text," Unesa University Press, Surabaya, 2015

[2] T. Licona, Charater (Character Issues), Jakarta: Earth Literacy, 2012.

[3] Ministry of Research, Technology and Higher Education, Guidelines for Submission of Textbook Writing Grant Program Proposals, Jakarta: Directorate of Intellectual Property Management, Directorate General of Research and Development Strengthening Ministry of Research, Technology and Higher Education, 2016.
[4] Government of Indonesia, "National Character Education Master Design (2010-2015)," Government of Indonesia, Jakarta, 2011.

[5] Warsono, Character Education Model at the State University of Surabaya, Surabaya: Unesa University Press, 2010.

[6] Tilaar, H. A. R. "Mengindonesia Etnisitas dan Identitas Bangsa Indonesia." 2007.

[7] DK A, Character Education: Strategy for Educating Children in a Global Age, Jakarta: PT. Gramedia Widiasarana, 2010.

[8] MS d. Hariyanto, Concept and Model of character education, Bandung: PT. Youth Rosdakarya, 2011.

[9] Moedjanto, G., and P. J. Suwarno. Kiat bangsa Indonesia menghadapi globalisasi dalam bidang budaya. Universitas Sanata Dharma, Penerbitan, 1995.

[10] Arif, Syaiful. Falsafah Kebudayaan Pancasila. Gramedia Pustaka Utama, 2016. 